Article

\title{
Lanthanum Ferrite Ceramic Powders: Synthesis, Characterization and Electrochemical Detection Application
}

\author{
Raluca Dumitru ${ }^{1, *}$, Sorina Negrea ${ }^{1}$, Adelina Ianculescu ${ }^{2}$, Cornelia Păcurariu ${ }^{1}$, \\ Bogdan Vasile ${ }^{2} \mathbb{D}$, Adrian Surdu ${ }^{2} \mathbb{D}$ and Florica Manea ${ }^{1, *}$ \\ 1 Faculty of Industrial Chemistry and Environmental Engineering, Politehnica University Timisoara, Piata \\ Victoriei No. 2, RO-300006 Timisoara, Romania; sorina.negrea@upt.ro (S.N.); cornelia.pacurariu@upt.ro (C.P.) \\ 2 Department of Oxide Materials Science and Engineering, Faculty of Applied Chemistry and Materials \\ Science, Polytehnic University of Bucharest, Gh. Polizu Street no.1-7, 011061 Bucharest, Romania; \\ a_ianculescu@yahoo.com (A.I.); bogdan.vasile@upb.ro (B.V.); adrian.surdu@upb.ro (A.S.) \\ * Correspondence: raluca.voda@upt.ro (R.D.); florica.manea@upt.ro (F.M.); Tel.: +40-256-404-188 (R.D.); \\ +40-256-403-070 (F.M.)
}

Received: 29 March 2020; Accepted: 27 April 2020; Published: 29 April 2020

\begin{abstract}
The perovskite-type lanthanum ferrite, $\mathrm{LaFeO}_{3}$, has been prepared by thermal decomposition of in situ obtained lanthanum ferrioxalate compound precursor, $\mathrm{LaFe}\left(\mathrm{C}_{2} \mathrm{O}_{4}\right)_{3} \cdot 3 \mathrm{H}_{2} \mathrm{O}$. The oxalate precursor was synthesized through the redox reaction between 1,2-ethanediol and nitrate ion and characterized by chemical analysis, infrared spectroscopy, and thermal analysis. $\mathrm{LaFeO}_{3}$ obtained after the calcination of the precursor for at least $550-800{ }^{\circ} \mathrm{C} / 1 \mathrm{~h}$ have been investigated by $\mathrm{X}$-ray diffraction (XRD), field emission scanning electron microscopy (FE-SEM), transmission electron microscopy (TEM), and high-resolution transmission electron microscopy (HRTEM). A boron-doped diamond electrode (BDD) modified with $\mathrm{LaFeO}_{3}$ ceramic powders at $550{ }^{\circ} \mathrm{C}\left(\mathrm{LaFeO}_{3} / \mathrm{BDD}\right)$ by simple immersion was characterized by cyclic voltammetry and tested for the voltammetric and amperometric detection of capecitabine (CCB), which is a cytostatic drug considered as an emerging pollutant in water. The modified electrode exhibited a complex electrochemical behaviour by several redox systems in direct relation to the electrode potential range. The results obtained by cyclic voltammetry (CV), differential-pulsed voltammetry (DPV), and multiple-pulsed amperometry proved the electrocatalytic effect to capecitabine oxidation and reduction and allowed its electrochemical detection in alkaline aqueous solution.
\end{abstract}

Keywords: lanthanum ferrite; oxalate precursor; electrochemical detection; capecitabine

\section{Introduction}

Perovskite-type oxides have received growing attention due to its diversity and performance [1-5]. Among the perovskite materials, lanthanum ferrite has been investigated intensively due to its potential applications in biosensors [6], (photo)catalysis [7], chemical sensors [8,9], electrochemistry field [10-15], magnetic, optical, and ferroelectric properties [16,17], environmentally-friendly pigments [18], spin electronic devices $[19,20]$, and more.

In general, electrochemical behaviors of perovskite-type oxides $\mathrm{LaFeO}_{3}$ have been investigated for various applications due to its high oxidation-reduction characteristics and electrical conductivity, e.g., electrocatalysts for oxygen evolution [11], photoelectrochemical water oxidation [12], hydrogen storage [13], gas sensor [14,15,21], voltammetric/amperometric detection of biomolecules [22], solid oxide fuel cells, and electrode materials [23,24]. 
Many methods have been studied and developed for obtaining $\mathrm{LaFeO}_{3}$ : sol-gel method $[25,26]$, mechanochemical [27], hydrothermal processes [28], molten salt synthesis [29], combustion method [30,31], microwave-assisted synthesis [32], co-precipitation of hydroxides [33], and polymerizable complex method [34]. Up to date, the precise control of perovskite-type oxides size, shape, and surface is still a challenge. The thermal decomposition of complex compounds precursors represent a simple, efficient, and reliable method for the synthesis of mixed oxides characterized by small particles at a relatively low temperature that depend on the system composition and properties [35,36]. However, it is required to find well-defined redox reaction conditions for precursor generating, which represents the key element to get an effective synthesis process of the mixed oxides characterized through desired advanced properties $[37,38]$. This is the reason for studying the optimum synthesis conditions (e.g., $\mathrm{pH}$, reaction temperature and time, reactant molar ratio) for each system and corresponding mixed oxides. For example, it is possible to conduct the oxidation of 1,2-ethanediol either glyoxylate anion [39,40] or oxalate anion, in the absence or presence of nitric acid, depending on the working conditions.

Herein, we reported an original method of in situ synthesis $\mathrm{LaFe}\left(\mathrm{C}_{2} \mathrm{O}_{4}\right)_{3} \cdot 3 \mathrm{H}_{2} \mathrm{O}$ oxalate compound, as a precursor of $\mathrm{LaFeO}_{3}$. This consists of a redox reaction of 1,2-ethanediol with metallic nitrates, in the presence of nitric acid, which was suitable for synthesis of other metallic oxides precursors [37,41-46]. The polyheterometallic oxalates, coordinative compounds in which the ligands are tetradentate, are more important because their thermal decomposition generate a large amounts of gases, which leads to nanomaterials with porous structures, high surface area, and homogeneous distribution, which are essential properties for practical sensing applications. The electrocatalytic characteristics in direct relation to the intrinsic morphostructural properties of $\mathrm{LaFeO}_{3}$ toward the electrooxidation or electroreduction process of the target analytes are responsible for the performance of the electrochemical detection. Its utility has been reported for gas sensing, e.g., $\mathrm{SO}_{2}$, formaldehyde, ethanol [21], and only a few for amperometric/voltammetric of biomolecules, e.g., guanine and uric acid [22], which allows the development of high sensitivity-electrochemical detection.

Capecitabine (CCB), chemically $\mathrm{N}^{4}$-pentoxycarbonyl-5'-deoxy-5-fluorocytidine, is a pyrimidine analogue, which acts inside the body as 5-fluorouracil, and commonly used cytostatic drugs in chemotherapy for treating colorectal and breast cancer $[47,48]$. Since the number of cancer patients has increased considerably, the CCB consumption increased continuously. For example, one-fold from the year 2004 to 2008 in France, and the environmental concentration of $3 \mathrm{ng} \mathrm{L}^{-1}$ was reported [49], which led to its presence into the water environment at a higher concentration. Few analytical methods including HPLC (high-performance liquid chromatography), LC-MS (liquid chromatography and mass spectrometry), and LC-MS/MS have been reported for CCB determination in biological samples [50-52]. Recently, electrochemical methods have been developed for CCB determination in biological samples using unmodified/modified carbon-based electrode materials, which considered the reduction process of CCB $[47,52,53]$. It is important to explore new electrode materials and techniques to develop sensitive, fast, simple, and cheap method for CCB determination. In this context, $\mathrm{LaFeO}_{3}$ was tested as an electrocatalyst in relation to its electrochemical behavior including the presence of redox systems to allow the CCB detection at $\mathrm{LaFeO}_{3}$ modified commercial BDD electrode material. To the best of our knowledge, no study related to $\mathrm{CCB}$ detection using $\mathrm{LaFeO}_{3}$-based electrode material has been reported. $\mathrm{LaFeO}_{3}$-modified boron doped diamond electrode $\left(\mathrm{LaFeO}_{3} / \mathrm{BDD}\right)$ was successfully used for the voltammetric and amperometric detection of $\mathrm{CCB}$ including both processes of $\mathrm{CCB}$ oxidation and reduction.

\section{Materials and Methods}

\subsection{Materials}

Pure $\mathrm{LaFeO}_{3}$ was obtained through the calcination in the temperature range of 550 to $800{ }^{\circ} \mathrm{C}$ of the $\mathrm{LaFe}\left(\mathrm{C}_{2} \mathrm{O}_{4}\right)_{3} \cdot 3 \mathrm{H}_{2} \mathrm{O}$ precursor, which was obtained previously. It was used as reagents: $\mathrm{La}\left(\mathrm{NO}_{3}\right)_{3} \cdot 6 \mathrm{H}_{2} \mathrm{O}$, $\left(\mathrm{Fe}\left(\mathrm{NO}_{3}\right)_{3} \cdot 9 \mathrm{H}_{2} \mathrm{O}\right.$, 1,2-ethanediol, $2 \mathrm{M} \mathrm{HNO}_{3}$ solution from Merck (Darmstadt, Germany). $\mathrm{NaOH}$ 
and capecitabine (CCB) used was an analytical-grade reagent from Merck. The doubly distilled and deionised water were used for preparing all solutions.

\subsection{Synthesis of $\mathrm{LaFe}\left(\mathrm{C}_{2} \mathrm{O}_{4}\right)_{3} \cdot 3 \mathrm{H}_{2} \mathrm{O}$ Oxalate Precursor and $\mathrm{LaFeO}_{3}$}

An aqueous solution containing lanthanum nitrate, iron nitrate, 1,2-ethanediol, and $2 \mathrm{M}$ nitric acid in a molar ratio of 1:1:3:2 that assured the solution $\mathrm{pH}$ of 3 was heated for $20 \mathrm{~min}$ at about $100{ }^{\circ} \mathrm{C}$ in a water bath. The synthesis conditions related to acidic $\mathrm{pH}$ of 3 were set-up based on the stoichiometry of the redox reaction related to the molar ratio. The temperature of about $100{ }^{\circ} \mathrm{C}$ is aqueous solution boiling temperature and the reaction time of $20 \mathrm{~min}$ was considered as the time for consuming reactants. The obtained precursor was purified by washing with acetone and dried in air. VARIAN SpectrAA 110 atomic absorption spectrophotometer (Varian, Palo Alto, CA, USA) was used to determine the metal content and a Carlo Erba 1108 elemental analyzer (Carlo Erba, Milan, Italy) was used for carbon and hydrogen analyzing. $\mathrm{LaFeC}_{6} \mathrm{O}_{15} \mathrm{H}_{6}$, calc./found: $\mathrm{La} \%$ : 27.09/27.21, $\mathrm{Fe} \%:$ 10.89/10.62, $\mathrm{C} \%$ : 14.04/13.95, and $\mathrm{H} \%: 1.17 / 1.22$. The precursor was calcinated in air under the temperature range from 550 to $800{ }^{\circ} \mathrm{C}$ with a heating rate of $10^{\circ} \mathrm{C} \mathrm{min}-1$ for time duration of one hour to get the $\mathrm{LaFeO}_{3}$ ceramic powders.

\subsection{Characterization of $\mathrm{LaFe}\left(\mathrm{C}_{2} \mathrm{O}_{4}\right)_{3} \cdot 3 \mathrm{H}_{2} \mathrm{O}$ Oxalate Precursor and $\mathrm{LaFeO}_{3}$}

The comparative Fourier transform infrared spectroscopy (FTIR) spectra of the $\mathrm{LaFeO}_{3}$ and oxalate precursor were recorded based on $\mathrm{KBr}$ pellets using a Jasco FT-IR spectrophotometer (Jasco, Tokyo, Japan) under the range of $4000-400 \mathrm{~cm}^{-1}$. Thermal measurements (TG, DTG, DSC) were carried out in artificial air flow of $20 \mathrm{~mL} \mathrm{~min}^{-1}$ and heating rate of $10 \mathrm{~K} \mathrm{~min}^{-1}$ using a NETZSCH-STA 449C instrument (Netzsch, Selb, Germany) under the temperature range of $25-1000{ }^{\circ} \mathrm{C}$, using alumina crucibles that were performed on the precursor.

X-ray diffraction (XRD) analyses performed at room temperature by a Rigaku Ultima IV diffractometer (Rigaku Co., Tokyo, Japan), using Ni-filtered CuK $\alpha$ radiation $(\lambda=1.5418$ Á) to characterize the phase purity and crystal structure of calcined powders. To refine the lattice parameters, the Rietveld method using the HighScore Plus 3.0e software (Rigaku Co., Tokyo, Japan) was applied.

Scanning electron microscopy (FE-SEM), using a high-resolution FEI QUANTA INSPECT F microscope (FEI Co., Eindhoven, The Netherlands) with a field emission gun, was used to assess the size and the agglomeration tendency of the $\mathrm{LaFeO}_{3}$ particles. In addition, transmission electron microscopy (TEM/HR-TEM) and selected area electron diffraction (SAED) investigations were performed for a high-accuracy assessment of the morphology and crystallinity degree of the constitutive $\mathrm{LaFeO}_{3}$ particles. Moreover, a TecnaiTM G ${ }^{2}$ F30 S-TWIN transmission electron microscope (FEI Co., Eindhoven, The Netherlands) was used to collect the bright-field and high-resolution images.

\subsection{Electrochemical Detection Application}

In order to easily test the electrochemical behaviour of $\mathrm{LaFeO}_{3}$ in the presence of capecitabine, the commercial BDD electrode produced by Windsor Scientific Ltd. (Slough, UK). For electroanalytic use, with a boron content of about 0.1 , it was modified by simple immersion in $5 \mathrm{mg} \mathrm{mL}^{-1} \mathrm{LaFeO}_{3}$ suspension. Unmodified and $\mathrm{LaFeO}_{3}$-modified boron-doped diamond electrode $\left(\mathrm{LaFeO}_{3} / \mathrm{BDD}\right)$ were electrochemically characterized and tested for detection using Autolab Pontentiostat/Galvanostat PGStat 302 (EcoChemie, Utrecht, The Netherlands) controlled with GPES 4.9 software (EcoChemie, Utrecht, The Netherlands) and a classical three-electrode cell. The saturated calomel electrode as a reference (SCE), the platinum electrode as a counter-electrode and the $\mathrm{LaFeO}_{3}$ modified/unmodified boron-doped diamond electrode modified $\left(\mathrm{LaFeO}_{3} / \mathrm{BDD}\right.$ and $\left.\mathrm{BDD}\right)$ as working electrodes were used for the electrochemical applications. The $\mathrm{LaFeO}_{3} / \mathrm{BDD}$ electrode was prepared by simple immersion prior to each electrochemical experiment running. The reproducibility of the modified surface was checked after stabilization by cyclic voltammetry and confirmed by a complete overlay of the cyclic voltammograms. 
After electrode immersion, 10 continuous repetitive cyclic voltammograms within the various potential ranges related to each application conditions were applied for the electrochemical stabilization of the electrode. The cyclic voltammetry, differential-pulsed voltammetry, and multiple-pulsed amperometry were applied for the electrochemical characterization and the detection applications.

All measurements were carried out in $0.1 \mathrm{M}$ sodium hydroxide supporting electrolyte at room temperature without a temperature control.

\section{Results and Discussion}

\subsection{Characterization of $\mathrm{LaFe}\left(\mathrm{C}_{2} \mathrm{O}_{4}\right)_{3} \cdot 3 \mathrm{H}_{2} \mathrm{O}$ Oxalate Precursor}

The method of the synthesis of the oxalate complex compound is based on the oxidation reaction of 1,2-ethanediol by the nitrate ion.

$$
\begin{gathered}
3 \mathrm{C}_{2} \mathrm{H}_{4}(\mathrm{OH})_{2}+\left(\mathrm{La}^{3+}+3 \mathrm{NO}_{3}{ }^{-}\right)+\left(\mathrm{Fe}^{3+}+3 \mathrm{NO}_{3}{ }^{-}\right)+2\left(\mathrm{H}^{+}+\mathrm{NO}_{3}{ }^{-}\right) \rightarrow \mathrm{LaFe}\left(\mathrm{C}_{2} \mathrm{O}_{4}\right)_{3} \cdot 3 \mathrm{H}_{2} \mathrm{O}_{(\mathrm{s})}+8 \mathrm{NO}_{(\mathrm{g})}+7 \mathrm{H}_{2} \mathrm{O}_{(\mathrm{g})} \\
\mathrm{NO}_{(\mathrm{g})}+\frac{1}{2} \mathrm{O}_{2(\mathrm{~g})} \rightarrow \mathrm{NO}_{2(\mathrm{~g})}
\end{gathered}
$$

The IR spectrum of oxalate precursor (Figure 1a) reveals the presence of water $\left[3410 \mathrm{~cm}^{-1}\left(v_{\mathrm{OH}}\right.\right.$, $\left.v_{\mathrm{H} 2 \mathrm{O}}\right), 794 \mathrm{~cm}^{-1}$ (lattice water)] [41,54], oxalate anions [as bidentate ligand: $1642 \mathrm{~cm}^{-1}\left(v_{\text {asym }(\mathrm{O}=\mathrm{C}-\mathrm{O})}\right)$ $+\delta_{\text {sym }}(\mathrm{HOH}), 1308 \mathrm{~cm}^{-1}\left(v_{\mathrm{sym}(\mathrm{O}=\mathrm{C}-\mathrm{O})}, 1051 \mathrm{~cm}^{-1}\left(v_{(\mathrm{C}-\mathrm{O})}\right)\right]$ [42]; as tetradentate ligand: $1445 \mathrm{~cm}^{-1}$ $\left.\left(v_{\mathrm{sym}(\mathrm{OCO})}\right), 915 \mathrm{~cm}^{-1}\left(\delta_{(\mathrm{OCO})}\right)\right][55]$, and metal-oxygen linkages [600-400 $\mathrm{cm}^{-1}: v_{(\mathrm{La}-\mathrm{O})}$ and $v_{(\mathrm{Fe}-\mathrm{O})}$ vibrations]. The IR spectra of $\mathrm{LaFeO}_{3}$ obtained after calcination at $550{ }^{\circ} \mathrm{C}$ (Figure $1 \mathrm{~b}$ ) and $700{ }^{\circ} \mathrm{C}$ (Figure 1c) exhibit only the bands characteristic for vibrations $v(\mathrm{La}-\mathrm{O})$ and $v(\mathrm{Fe}-\mathrm{O})$ in the range of $600-400 \mathrm{~cm}^{-1}[43,44]$.

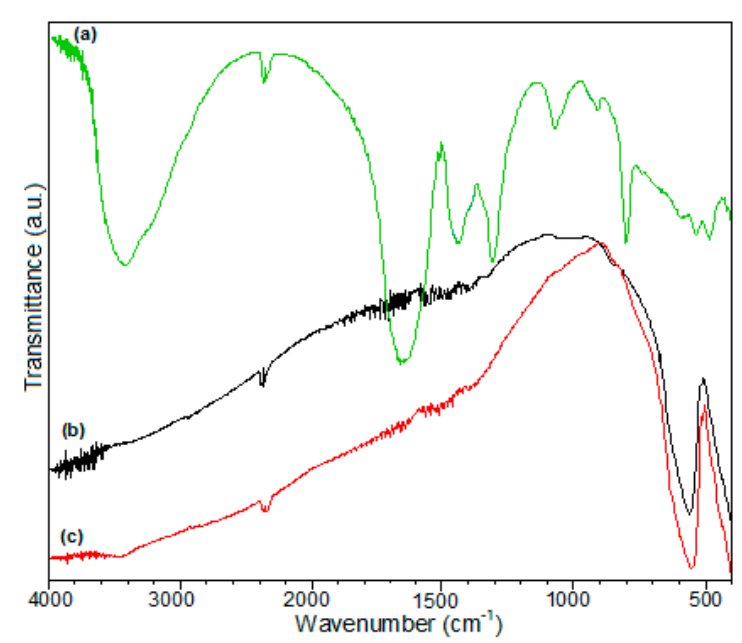

Figure 1. IR vibrational spectra of $\mathrm{LaFe}\left(\mathrm{C}_{2} \mathrm{O}_{4}\right)_{3} \cdot 3 \mathrm{H}_{2} \mathrm{O}$ compound (a), $\mathrm{LaFeO}_{3} 550{ }^{\circ} \mathrm{C}(\mathbf{b})$, and $\mathrm{LaFeO}_{3}$ $700^{\circ} \mathrm{C}(\mathbf{c})$.

No other bands characteristic to the presence of the water and the oxalate anion can be noticed due to thermal decomposition of the precursor, known as the $\mathrm{LaFe}\left(\mathrm{C}_{2} \mathrm{O}_{4}\right)_{3} \cdot 3 \mathrm{H}_{2} \mathrm{O}$ oxalate compound, which are further detailed and presented.

$\mathrm{La}(\mathrm{III})-\mathrm{Fe}(\mathrm{III})$ oxalate trihydrate decomposes (Figure 2) via three steps with the formation of a carbonate intermediate.

The first step of thermal decomposition of $\mathrm{LaFe}\left(\mathrm{C}_{2} \mathrm{O}_{4}\right)_{3} \cdot 3 \mathrm{H}_{2} \mathrm{O}\left(25-160^{\circ} \mathrm{C}\right.$, mass loss: found $11.10 \%$, calcd. $10.53 \%$ ) is associated with an endothermic effect, and the mass loss is attributed to the evolving of the lattice water [43]. 
The next decomposition step $\left(160-280^{\circ} \mathrm{C}\right)$ characterized by an endothermic effect is due to the degradation of the terminal oxalate anions (mass loss, found $10.40 \%$, calcd. $10.92 \%$ ) with the formation of a carbonate intermediate, $\left[\mathrm{CO}_{3} \mathrm{La}\left(\mathrm{C}_{2} \mathrm{O}_{4}\right) \mathrm{FeCO}_{3}\right][44,45]$.

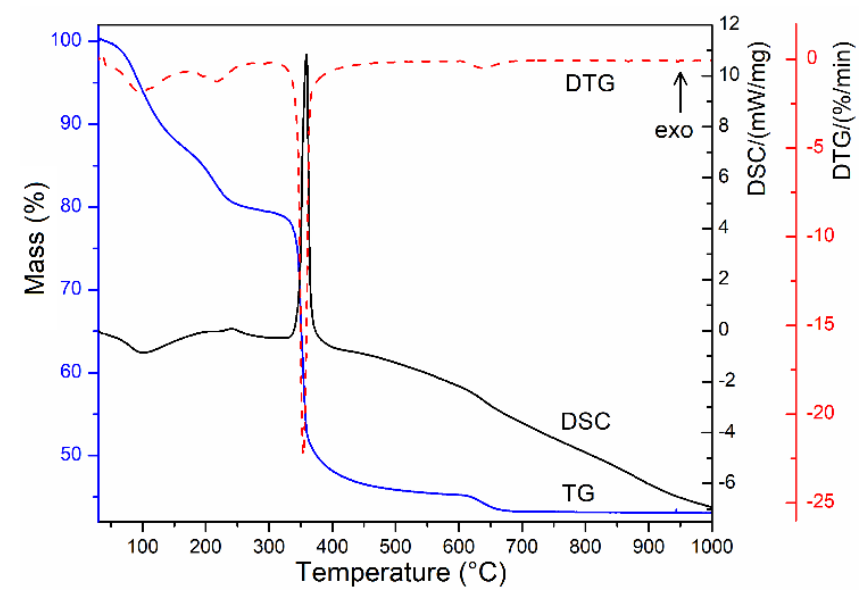

Figure 2. Thermal curves TG (thermogravimetric), DTG (derivative thermogravimetric), and DSC (differential scanning calorimetry) of $\mathrm{LaFe}\left(\mathrm{C}_{2} \mathrm{O}_{4}\right)_{3} \cdot 3 \mathrm{H}_{2} \mathrm{O}$ compound.

The strong exothermic effect that characterizes the third step $\left(280-550{ }^{\circ} \mathrm{C}\right)$ is attributed to the oxidative degradation of $\mathrm{CO}_{3}^{2-}$ and the last $\mathrm{C}_{2} \mathrm{O}_{4}^{2-}$ with the formation of the lanthanum ferrite, which retains small amounts of carbon dioxide (mass loss: found $34.03 \%$, calcd. $34.32 \%$ ). In the temperature range of $550-700{ }^{\circ} \mathrm{C}$, the mass loss corresponds to the removal of carbon dioxide.

Simultaneously, with this endothermic decomposition step, an exothermic process of crystallization, involving the formation of the perovskite skeleton from an amorphous phase also takes place, so that, only a small and flattened endothermic peak, as a resultant of the two opposite processes, can be observed on the DSC curve $[45,46]$.

The thermal analysis suggests the following sequence for decomposition of $\mathrm{LaFe}\left(\mathrm{C}_{2} \mathrm{O}_{4}\right)_{3} \cdot 3 \mathrm{H}_{2} \mathrm{O}$ in static air atmosphere.

$$
\begin{gathered}
\mathrm{LaFe}\left(\mathrm{C}_{2} \mathrm{O}_{4}\right)_{3} \cdot 3 \mathrm{H}_{2} \mathrm{O}_{(\mathrm{s})} \stackrel{(I)}{\longrightarrow} 3 \mathrm{H}_{2} \mathrm{O}_{(\mathrm{g})}+\mathrm{LaFe}\left(\mathrm{C}_{2} \mathrm{O}_{4}\right)_{3(\mathrm{~s})} \\
\mathrm{LaFe}\left(\mathrm{C}_{2} \mathrm{O}_{4}\right)_{3(\mathrm{~s})} \stackrel{(I I)}{\rightarrow} 2 \mathrm{CO}_{(\mathrm{g})}+\mathrm{CO}_{3} \mathrm{LaC}_{2} \mathrm{O}_{4} \mathrm{FeCO}_{3(\mathrm{~s})} \\
\mathrm{CO}_{3} \mathrm{LaC}_{2} \mathrm{O}_{4} \mathrm{FeCO}_{3(\mathrm{~s})} \stackrel{+1 / 2 \mathrm{O}_{2}(I I I)}{\longrightarrow} 4 \mathrm{CO}_{2(\mathrm{~g})}+\mathrm{LaFeO}_{3(\mathrm{~s})}
\end{gathered}
$$

\subsection{Characterization of $\mathrm{LaFeO}_{3}$ Powders}

The room-temperature $X$-ray diffraction patterns presented in Figure 3a show that the as-prepared precursor, as well as the powder that resulted after calcination at $500{ }^{\circ} \mathrm{C}$, are amorphous, while, in the powders obtained at higher temperatures $\left(T \geq 550{ }^{\circ} \mathrm{C}\right)$, the main reflections specific to the $\mathrm{LaFeO}_{3}$ perovskite phase with orthorhombic Pbnm(62) structure were detected. For the powder calcined at $550{ }^{\circ} \mathrm{C}$, the broader profile and the lower intensity of the diffraction peaks as well as the higher background of the corresponding diffraction pattern suggested that a significant amount of an amorphous phase still persists in the sample. The increase of the annealing temperature from 550 to $800{ }^{\circ} \mathrm{C}$ induces the reduction of the amount of amorphous phase, concurrently with the gradual increase of the crystallintiy degree and purity of the perovskite phase reflected in the enhancement of intensity of the main diffraction lines of $\mathrm{LaFeO}_{3}$. 


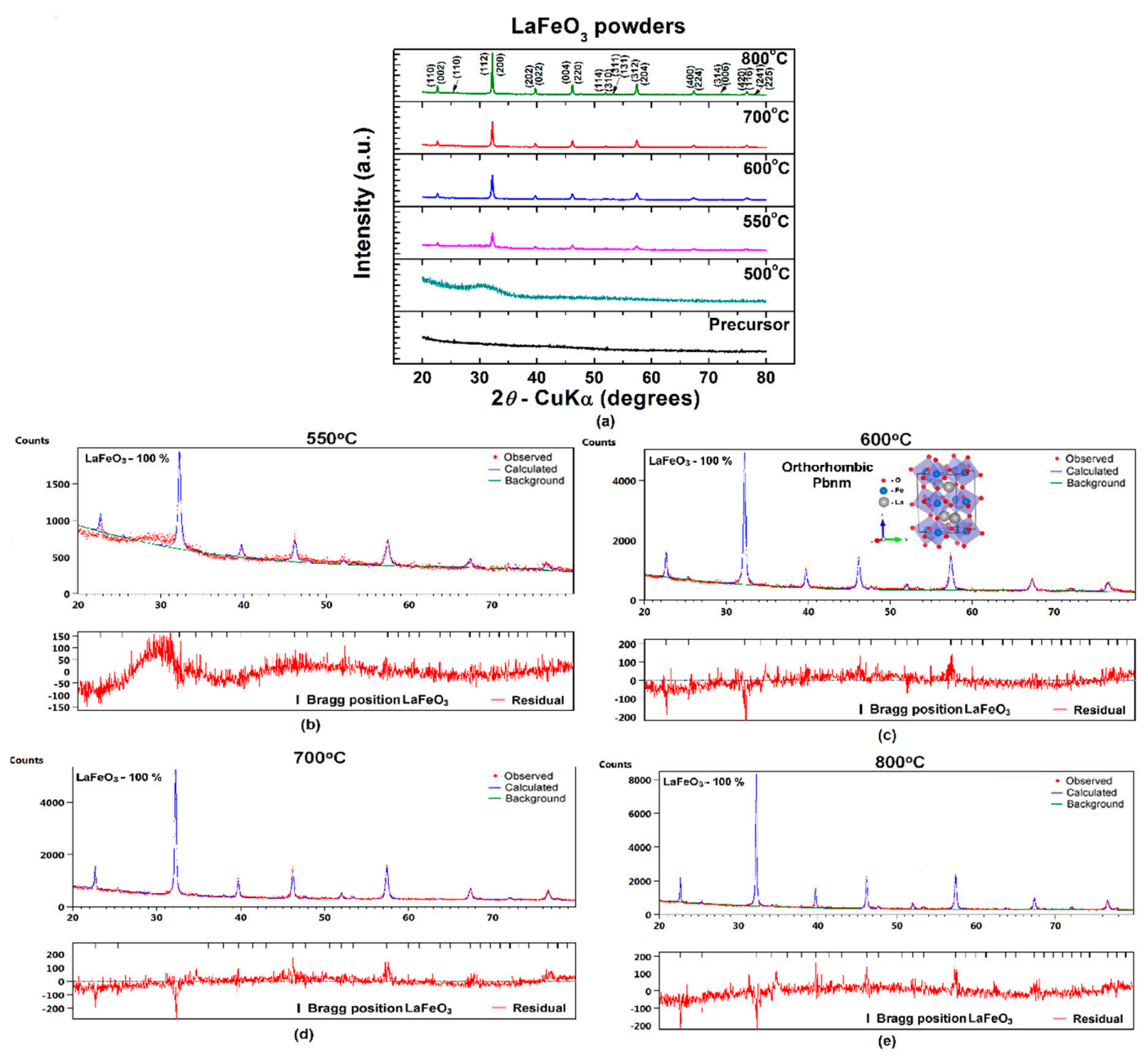

Figure 3. (a) Room-temperature XRD patterns and (b-e) results of Rietveld analysis of XRD data for $\mathrm{LaFeO}_{3}$ powders calcined at various temperatures: (b) 550, (c) 600, (d) 700, and (e) $800{ }^{\circ} \mathrm{C}$.

The results of the Rietveld analysis of the room temperature diffraction data of $\mathrm{LaFeO}_{3}$ powders thermally treated at various temperatures in the temperature range of $550-800{ }^{\circ} \mathrm{C}$ are presented in Figure $3 \mathrm{~b}-\mathrm{e}$. The quality of the samples is indicated by the parameters provided by the Rietveld refinement, $R$ expected $\left(R_{\exp }\right), R$ profile $\left(R_{\mathrm{p}}\right)$, weighted $R$ profile $\left(R_{\mathrm{wp}}\right)$, and goodness of fit $\left(\chi^{2}\right)$, which show values in good agreement with other literature data [56] (Table 1).

The dependence of the lattice parameters, $a, b$, and $c$ and, consequently, of the unit cell volume $V$, on the calcination temperature, exhibits a decreasing trend (Table 1). The progress of the crystallization process involves a clear contraction of the unit cell, as shown in Figure 4a.

Even if the coarsening process evolves with the increase of annealing temperature, the values of the average crystallite size, also determined from the $\mathrm{XRD}$ data, are kept in the nanometric range, varying from $17.5 \mathrm{~nm}$ for the $\mathrm{LaFeO}_{3}$ powder calcined at $550{ }^{\circ} \mathrm{C}$ to $36.7 \mathrm{~nm}$ in the case of the powder calcined at $800^{\circ} \mathrm{C}$. The significantly lower rate of increasing both the proportion of crystalline phase with respect to the amount of amorphous phase and the crystallite size with the temperature increase for $\mathrm{LaFeO}_{3}$ particles investigated in this study, in comparison to the steeper increase of these characteristics in the case of $\mathrm{BiFeO}_{3}$ powders calcined in the same temperature range reported earlier, which can be related to the higher refractoriness of lanthanum relative to that of $B i$ in the ferrite-type compounds [44]. As expected, the increase of the crystallite size determines a lattice relaxation proved by the clear decrease in the lattice micro-strains when increasing the calcination temperature (Figure $4 \mathrm{~b}$ ). Therefore, the increase of the crystallite size involves the reduction in the inter-atomic spacing, which results in the contraction of the unit cell. 
Table 1. Rietveld refined structural parameters for $\mathrm{LaFeO}_{3}$ powders annealed at various temperatures.

\begin{tabular}{|c|c|c|c|c|c|}
\hline \multirow{2}{*}{\multicolumn{2}{|c|}{$\begin{array}{c}\text { Compound } \\
\text { Annealing Temperature }\left({ }^{\circ} \mathrm{C}\right)\end{array}$}} & \multicolumn{4}{|c|}{$\mathrm{LaFeO}_{3}$} \\
\hline & & 550 & 600 & 700 & 800 \\
\hline \multicolumn{2}{|c|}{ Crystal System } & \multicolumn{4}{|c|}{ Orthorhombic (ICCD no. 04-013-6775) } \\
\hline \multicolumn{2}{|c|}{ Space Group } & \multicolumn{4}{|c|}{ Pbnm (62) } \\
\hline \multirow{3}{*}{$\begin{array}{c}\text { Lattice } \\
\text { parameters }(\AA)\end{array}$} & $A$ & $5.562 \pm 0.011$ & $5.562 \pm 0.003$ & $5.561 \pm 0.002$ & $5.561 \pm 0.002$ \\
\hline & $B$ & $7.856 \pm 0.016$ & $7.856 \pm 0.004$ & $7.856 \pm 0.003$ & $7.856 \pm 0.002$ \\
\hline & C & $5.558 \pm 0.012$ & $5.558 \pm 0.003$ & $5.558 \pm 0.002$ & $5.558 \pm 0.001$ \\
\hline \multicolumn{2}{|c|}{ Unit cell volume, $V\left(\AA^{3}\right)$} & 242.9 & 242.8 & 242.8 & 242.8 \\
\hline \multirow{4}{*}{$R$ factors $(\%)$} & $R_{\exp }$ & 5.520 & 5.612 & 5.892 & 5.664 \\
\hline & $R_{\mathrm{p}}$ & 5.244 & 4.814 & 5.488 & 5.041 \\
\hline & $R_{\mathrm{wp}}$ & 6.416 & 5.845 & 6.578 & 6.057 \\
\hline & $\chi^{2}$ & 1.351 & 1.085 & 1.246 & 1.143 \\
\hline
\end{tabular}

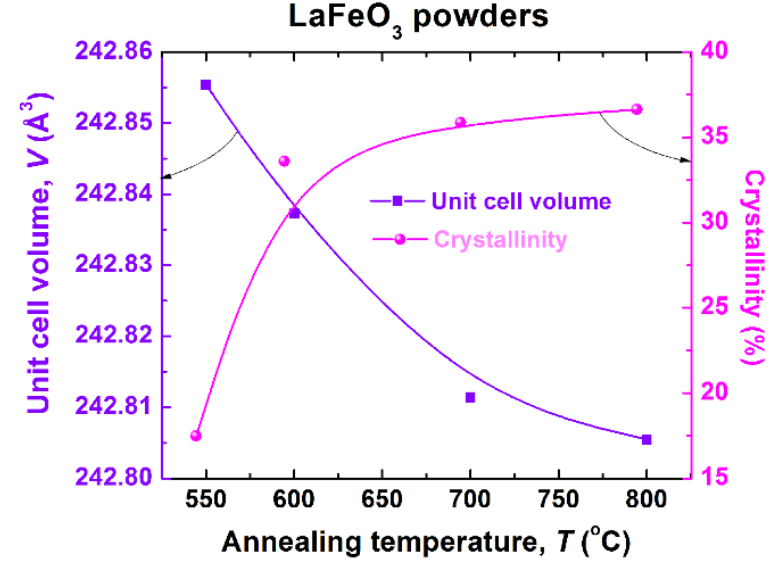

(a)

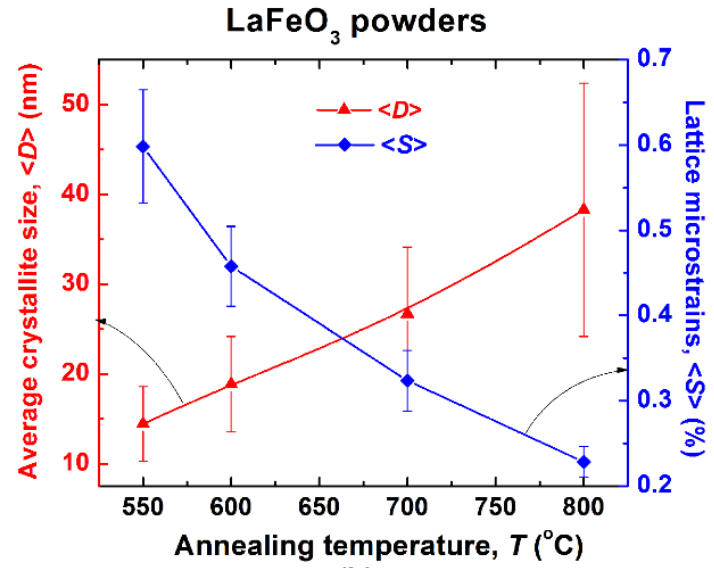

(b)

Figure 4. Annealing temperature dependence of: (a) unit cell volume and crystallinity and (b) average crystallite size and lattice microstrains.

For all the powders under investigation, the FE-SEM analyses showed the clear tendency of the $\mathrm{LaFeO}_{3}$ particles to form large (of few tens of microns), non-uniform (as shape and size) aggregates, with a spongeous aspect, as indicated by the FE-SEM overall images of Figure 5a,c,e,g.

The higher magnification FE-SEM images have taken in order to notice the structuring inside the aggregates showed that the powder calcined at $550{ }^{\circ} \mathrm{C}$ consists of very small-sized particles (most of them below $15 \mathrm{~nm}$ ). The value of the average particle size is difficult to be estimated mainly because of the presence of a significant amount of amorphous phase (as XRD data indicated), which impeded the clear distinction of the particle's boundaries (Figure 5b). The structuring inside the aggregates becomes better highlighted in the case of the powders that resulted after annealing at 600 and especially at $700{ }^{\circ} \mathrm{C}$ (Figure 5d,f). The presence of the amorphous phase is still noticed along with the crystalline aggregates in the $\mathrm{LaFeO}_{3}$ powder calcined at $600{ }^{\circ} \mathrm{C}$ (Figure $5 \mathrm{~d}$ ), while the aggregates of the powder calcined at $600{ }^{\circ} \mathrm{C}$ seems to consist of porous agglomerates of 300-500 nm, inside which nanometric particles (of 25-35 nm), linked together by necks and form 3D networks are observed (Figure 5f). Taking into account the values of the average crystallite size determined from the XRD data, one can assume that the nanoparticles of the $\mathrm{LaFeO}_{3}$ powders resulted after annealing in the temperature range of $550-700{ }^{\circ} \mathrm{C}$ are single crystals. The FE-SEM detail image of Figure $5 \mathrm{~h}$ indicates that the $\mathrm{LaFeO}_{3}$ powder calcined at $800{ }^{\circ} \mathrm{C}$ consists of partially-sintered blocks, formed of nano-sized crystalline grains (with an average grain size $\langle D G>=69.4 \mathrm{~nm}$ ) with well-defined boundaries and triple junctions, between which a small amount of intergranular porosity is detected. In some regions, the grain 
growth process, favored by the higher annealing temperature, induced a coalescence of some smaller grains, with the formation of the larger ones (of 200-300 nm) as well as the concurrent modification of some intergranular pores into intragranular pores (Figure $5 \mathrm{~h}$ ). Considering the value of the average crystallite size obtained from the XRD data, the values of the grain/particle size inside the agglomerates estimated from the FE-SEM observations suggest that the grains of the $\mathrm{LaFeO}_{3}$ powder calcined at $800{ }^{\circ} \mathrm{C}$ exhibit a polycrystalline nature. Thus, we were able to estimate that the smaller grains consist of 2-3 crystallites, while the larger ones are formed from 6-10 crystallites.

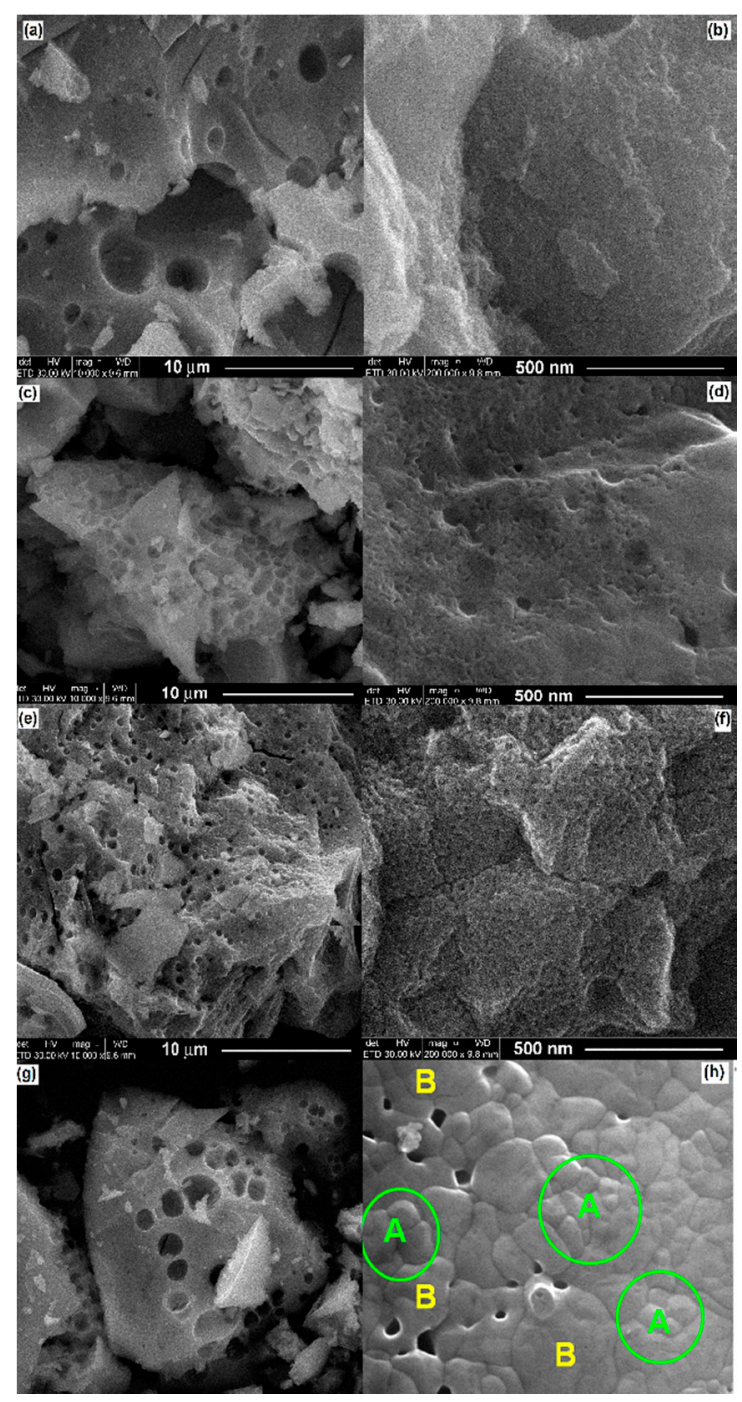

Figure 5. FE-SEM overall $(\mathbf{a}, \mathbf{c}, \mathbf{e}, \mathbf{g})$ and detail $(\mathbf{b}, \mathbf{d}, \mathbf{f}, \mathbf{h})$ images of $\mathrm{LaFeO}_{3}$ powders calcined at various temperatures: $(\mathbf{a}, \mathbf{b})-550{ }^{\circ} \mathrm{C},(\mathbf{c}, \mathbf{d})-600{ }^{\circ} \mathrm{C},(\mathbf{e}, \mathbf{f})-700{ }^{\circ} \mathrm{C}$, and $(\mathbf{g}, \mathbf{h})-800{ }^{\circ} \mathrm{C}$ (green circles A-groups of nano-sized grains, yellow $\mathrm{B}$-larger grains formed by the coalescence of the smaller ones).

The FE-SEM observations are sustained by the results of TEM investigations. Thereby, the lower magnification TEM images of Figures $6 a$ and $7 a$ clearly indicate the presence of the submicronic aggregates of various sizes and with irregular shapes. The higher magnification TEM images emphasized the structuring of the aggregates, which are formed by particles of 10-20 nm in the case of the powder calcined at $550{ }^{\circ} \mathrm{C}$ (Figure $6 \mathrm{~b}$ ) and of $\sim 40-50 \mathrm{~nm}$ for powder calcined at $700{ }^{\circ} \mathrm{C}$ (Figure $7 \mathrm{~b}$ ). 

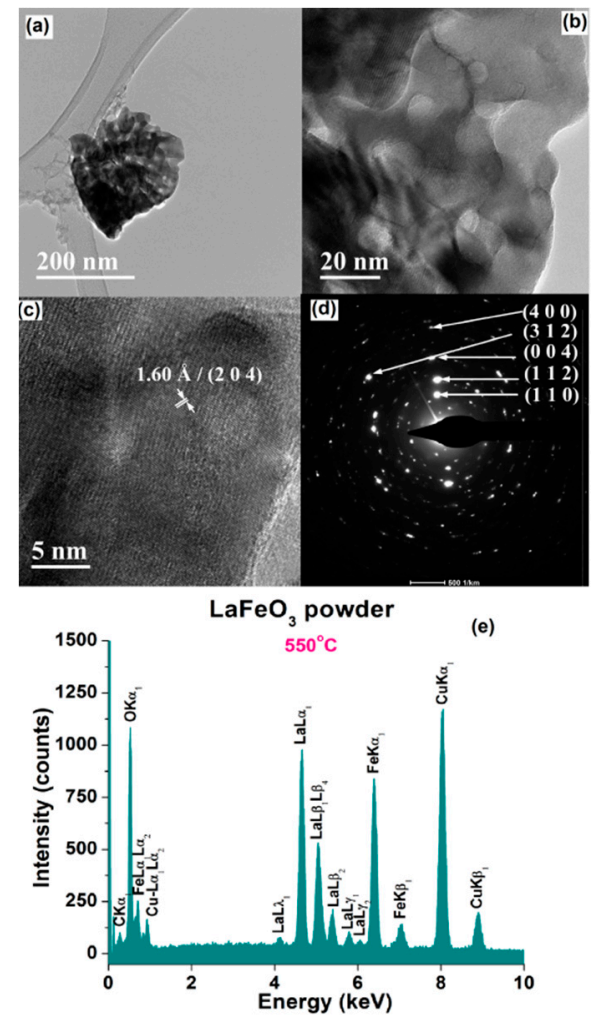

Figure 6. (a,b) TEM images of various magnifications: (c) HRTEM image, (d) SAED pattern, and (e) EDX spectrum for $\mathrm{LaFeO}_{3}$ powder calcined at $550{ }^{\circ} \mathrm{C}$.

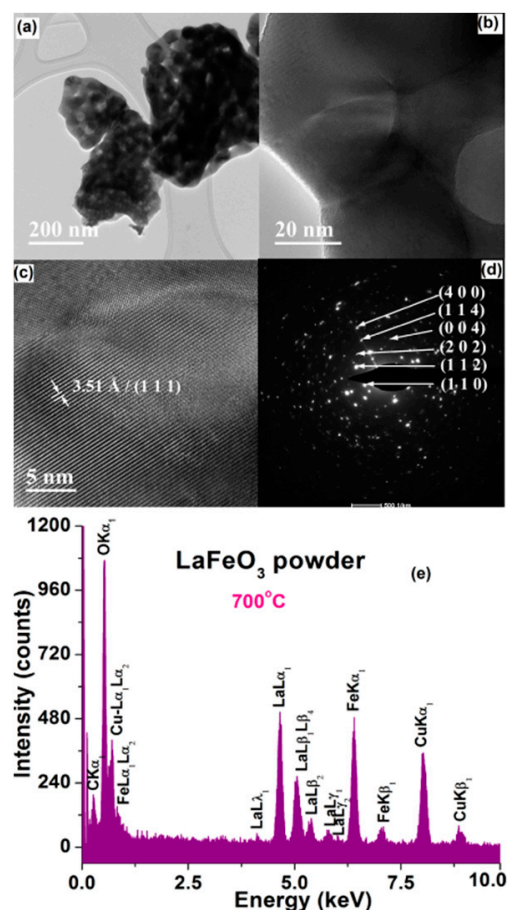

Figure 7. (a,b) TEM images of various magnification, (c) HRTEM image, (d) SAED pattern, and (e) EDX spectrum for $\mathrm{LaFeO}_{3}$ powder calcined at $700{ }^{\circ} \mathrm{C}$.

The HRTEM image of the $\mathrm{LaFeO}_{3}$ sample calcined at $550{ }^{\circ} \mathrm{C}$ indicate the presence of some small particles with sizes of $6.5-10 \mathrm{~nm}$. Inside these particles, oriented fringes spaced at $1.60 \AA$ corresponding to the crystalline plane (2 04 ) were noticed (Figure 6c). It is difficult to notice these small particles 
because they are usually embedded into an amorphous matrix. In the case of the powder calcined at $700{ }^{\circ} \mathrm{C}$, the lower amount of amorphous phase allowed to better visualize the long-range ordered fringes, so that the HRTEM image clearly emphasizes long-range ordered fringes spaced at $3.51 \AA$, corresponding to the crystalline plane (1 111 ) (Figure 7c).

For both powders, the high crystallinity degree of the randomly oriented particles is also pointed out by the bright spots, forming concentric diffraction rings, assigned to several crystalline planes of the perovskite $\mathrm{LaFeO}_{3}$ phase in the specific SAED (selected area electron diffraction) patterns of Figures $6 \mathrm{~d}$ and $7 \mathrm{~d}$.

EDX (energy-dispersive X-ray analysis) analyses were also performed in order to determine the elemental composition of the $\mathrm{LaFeO}_{3}$ powders under investigation. The EDX spectra show only the presence of $\mathrm{La}, \mathrm{Fe}$, and $\mathrm{O}$ species, which indicates that no contamination took place during the powders processing (Figures 6e and 7e).

The morphostructural properties of the $\mathrm{LaFeO}_{3}$ are different functions of the calcination temperature, and the lowest particles were obatined at a relatively low temperature of $550{ }^{\circ} \mathrm{C}$ in comparison with other materials synthesized by the same method [43-46].

\subsection{Electrochemical Characterization and Detection Application}

Based on the morphostructural properties of $\mathrm{LaFeO}_{3}$ ceramic powders, which were presented above and discussed in relation with the electroactivity capacity and electro-catalytical effect, for testing in electrochemical detection application $\mathrm{LaFeO}_{3}$ synthesized at $550^{\circ} \mathrm{C}$. The comparative electrochemical behaviours of unmodified and $\mathrm{LaFeO}_{3}$-modified BDD electrodes in alkaline medium was studied by cyclic voltammetry $(\mathrm{CV})$ and the results are presented in Figure $8 \mathrm{a}, \mathrm{b}$. It can be noticed that the oxidation and coupled reduction peak for $\mathrm{LaFeO}_{3} / \mathrm{BDD}$, which can be attributed to $\mathrm{Fe}^{2+/} \mathrm{Fe}^{3+}$ and $\mathrm{Fe}^{3+} / \mathrm{Fe}^{4+}$ redox systems according to the literature [12]. In addition, capacitive component of the current is much larger in comparison with the unmodified BDD electrode, which is expected for the electrocatalyst electrode material. Thus, a depolarization effect toward the oxygen evolution reaction and a polarization effect on the hydrogen evolution reaction were manifested through $\mathrm{LaFeO}_{3}$ on the BDD electrode surface. The electrocatalytic activity of the $\mathrm{LaFeO}_{3}$ sample is relevant with the crystalline size and the rate of oxygen migration from bulk towards the surface [57,58], which relates to the applied potential range.

Both unmodified and $\mathrm{LaFeO}_{3} / \mathrm{BDD}$ electrodes were tested in the presence of $5 \mu \mathrm{M} \mathrm{CCB}$ and no signal was found at an unmodified BDD electrode (the results are not shown here). The behavior of the $\mathrm{LaFeO}_{3} / \mathrm{BDD}$ electrode in the presence of various CCB concentrations ranged from 2.5 to $22.5 \mu \mathrm{M}$ is shown in Figure 9a and it can be noticed that the current grows with CCB concentration increasing for two potential values, which can be considered as detection potentials. The redox systems manifested to $-0.4 \mathrm{~V} / \mathrm{SCE}$ and $+0.4 \mathrm{~V} / \mathrm{SCE}$ showed a strong promoting effect and high stability towards the electrochemical oxidation of CCB. The linear dependence between the current and CCB concentration was found at the potential value of $-0.4 \mathrm{~V} / \mathrm{SCE}$ and $0.4 \mathrm{~V} / \mathrm{SCE}$ (Figure $9 \mathrm{~b}$ ). Under this potential range, no increase of any cathodic reduction peak was noticed for the $\mathrm{LaFeO}_{3} / \mathrm{BDD}$ electrode, which informed that the CCB oxidation is not reversible.

Taking into account that differential-pulsed voltammetry technique (DPV) exhibit the advantages of the higher sensitivity in comparison with CV, this technique was tested in various working conditions related to modulation amplitude and the step potential. The detection results depended by the direction of the applied potential scanning. No reproducible results were achieved for anodic scanning, which suggest that this technique is not appropriate for the CCB detection based on its oxidation process. However, very good results were reached by potential scanning in a cathodic sense under a modulation amplitude of $0.2 \mathrm{~V}$ and step potential of $0.05 \mathrm{~V}$ (Figure 10). Cathodic peak characteristics to CCB reduction was found at the potential value of $-1.02 \mathrm{~V} / \mathrm{SCE}$, which should be due to the oxidation-based activation of the electrode surface. The cathodic peak current increased linearly 
with $\mathrm{CCB}$ concentration for two concentration ranges below $2.5 \mu \mathrm{M} \mathrm{CCB}$ and ranged from $2.5 \mu \mathrm{M}$ to $17 \mu \mathrm{M}$ CCB (see inset of Figure 10).

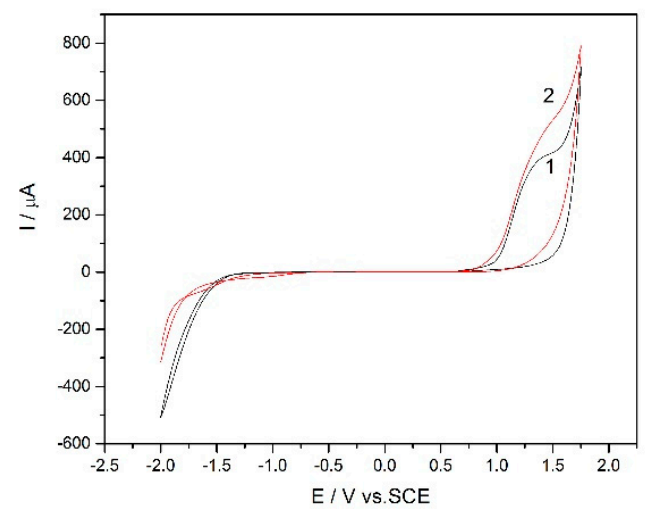

(a)

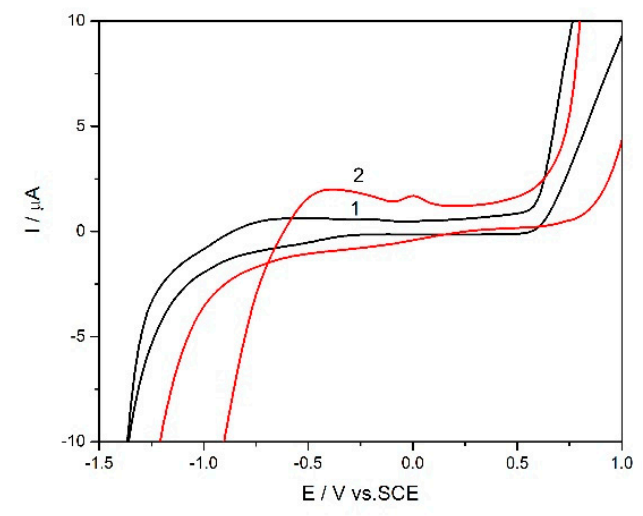

(b)

Figure 8. (a) Cyclic voltammetry recorded at an unmodified BDD electrode (curve 1 ) and $\mathrm{LaFeO}_{3} / \mathrm{BDD}$ electrode (curve 2) in $0.1 \mathrm{M} \mathrm{NaOH}$ supporting the electrolyte, scan rate of $0.05 \mathrm{Vs}^{-1}$. (b) Detail of cyclic voltammetry recorded at an unmodified BDD electrode (curve 1) and $\mathrm{LaFeO}_{3} / \mathrm{BDD}$ electrode (curve 2) in $0.1 \mathrm{M} \mathrm{NaOH}$ supporting electrolyte.
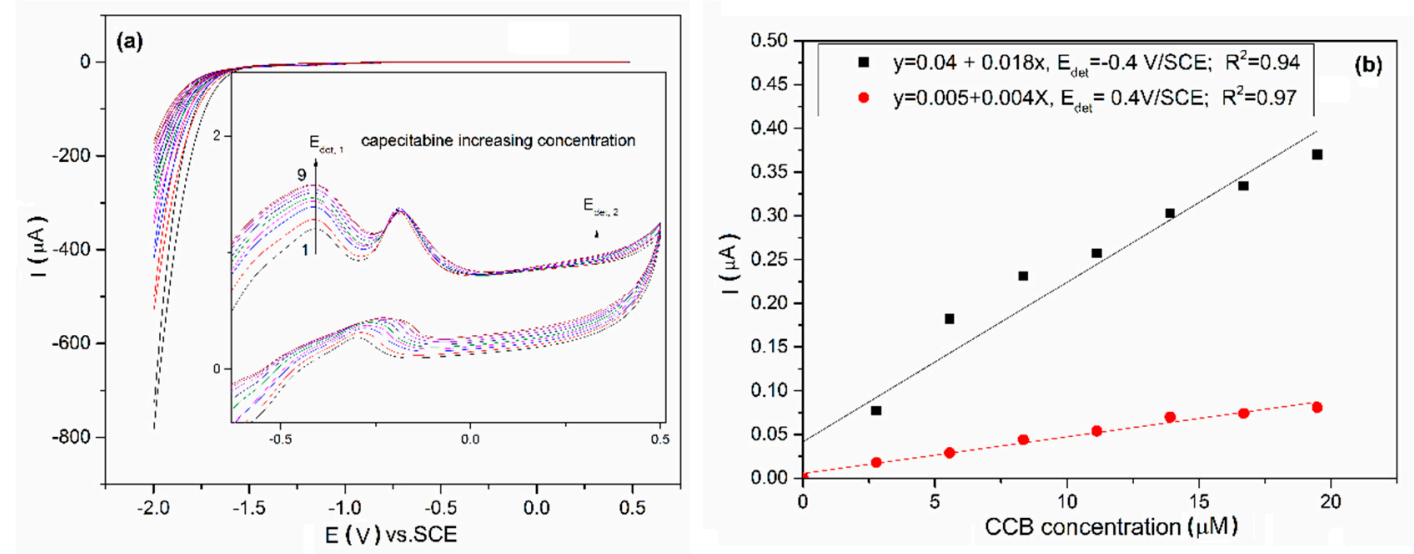

Figure 9. (a) Cyclic voltammetry recorded at $\mathrm{LaFeO}_{3} / \mathrm{BDD}$ electrode in $0.1 \mathrm{M} \mathrm{NaOH}$ (curve 1) and in the various CCB concentrations ranged from $2.5 \mu \mathrm{M}$ to $22.5 \mu \mathrm{M}$ (curves 2-9), scan rate of $0.05 \mathrm{Vs}^{-1}$. (b) Calibration plots of anodic peak with various CCB concentrations ranged from $2.5 \mu \mathrm{M}$ to $22.5 \mu \mathrm{M}$ (curves 2-9).

One of the most desired technique for electro-detection is chronoamperometry (CA) due to its simplicity and easy application, which was tested for the $\mathrm{LaFeO}_{3} / \mathrm{BDD}$ electrode in CCB detection. A very low signal was achieved (the results are not shown here), which led to testing three-levels potential based multiple-pulsed amperometry (MPA) as a variant of CA. The potential levels were selected based on the results of voltammetry techniques of both CV and DPV, considering the oxidation and reduction processes related to CCB. According to the literature [59], the oxidation steps of the CCB to 5"-deoxy-5-fluorocytudine and further to five fluorouracil and its reduction to dihydrofluorouracil should be considered based on the previous results of CV and DPV related to the potential range and scanning sense. Amperograms recorded by MPA are presented in Figure 11. The pulses were applied continuously using the following scheme:

(a) $-1.1 \mathrm{~V} / \mathrm{SCE}$ for a duration of $50 \mathrm{~ms}$, where CCB reduction occurred,

(b) $-0.4 \mathrm{~V} / \mathrm{SCE}$ for a duration of $50 \mathrm{~ms}$, where $\mathrm{CCB}$ oxidation occurred involving $\mathrm{Fe}^{2+} / \mathrm{Fe}^{3+}$ redox system, 
(c) $0.4 \mathrm{~V} / \mathrm{SCE}$ for a duration of $50 \mathrm{~ms}$, where further CCB oxidation occurred involving $\mathrm{Fe}^{3+} / \mathrm{Fe}^{4+}$ redox system besides an oxygen evolution reaction starting.

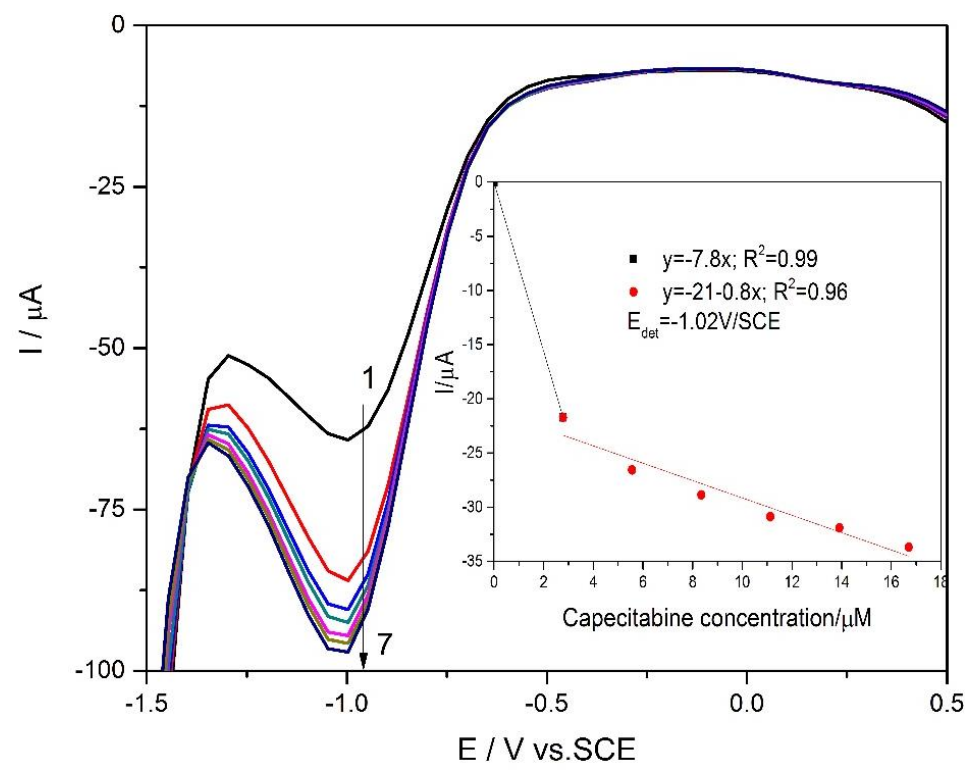

Figure 10. Differential-pulsed voltammograms recorded at $\mathrm{LaFeO}_{3} / \mathrm{BDD}$ electrode in $0.1 \mathrm{M} \mathrm{NaOH}$ (curve 1) and in the various CCB concentrations ranged from $2.5 \mu \mathrm{M}$ to $17 \mu \mathrm{M}$ (curves 2-7), scan rate of $0.05 \mathrm{Vs}^{-1}$, modulation amplitude of $0.2 \mathrm{~V}$, and step potential of $0.05 \mathrm{~V}$.

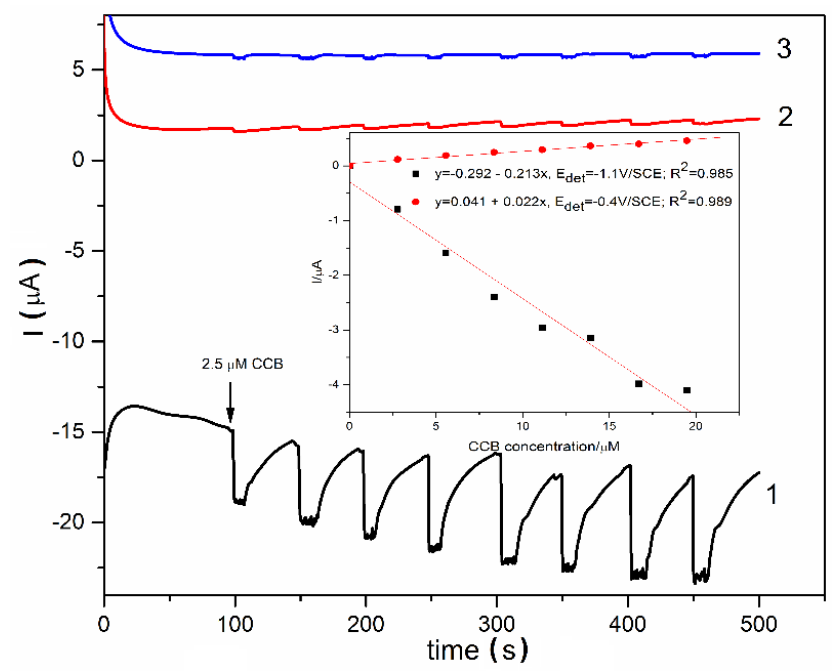

Figure 11. Multiple-pulsed amperograms (MPAs) recorded at the $\mathrm{LaFeO}_{3} / \mathrm{BDD}$ electrode in a $0.1 \mathrm{M}$ $\mathrm{NaOH}$ supporting electrolyte and adding $2.5 \mu \mathrm{M}$ CCB concentrations at three potential levels applied for time duration of $50 \mathrm{~ms}$ : $-1.1 \mathrm{~V} / \mathrm{SCE}$ (curve 1), $-0.4 \mathrm{~V} / \mathrm{SCE}$ (curve 2), and 0.4 V/SCE (curve 3). Inset: Calibration plots of current vs CCB concentrations for $-1.1 \mathrm{~V} / \mathrm{SCE}$ and $-0.4 \mathrm{~V} / \mathrm{SCE}$.

The electroanalytical parameters for CCB detection related to sensitivity, the lowest limit of detection, and the limit of quantification determined for each above-mentioned technique are gathered in Table 2.

In comparison with reported results related to CCB electrochemical detection presented in Table 3, it can be noticed that the superiority of this electrode in relation with a very good limit of detection (LOD) and considering its availability for either CCB oxidation or CCB reduction with the mention that the literature reported only the detection procedure based on $\mathrm{CCB}$ reduction. 
Table 2. The electroanalytical parameters for CCB determination using $\mathrm{LaFeO}_{3} / \mathrm{BDD}$ electrode.

\begin{tabular}{|c|c|c|c|c|c|c|c|}
\hline Technique & $\begin{array}{l}\text { Mechanism } \\
\text { Detection }\end{array}$ & $\begin{array}{l}\text { Detection } \\
\text { Potential/ } \\
\text { V vs. SCE }\end{array}$ & $\begin{array}{c}\text { Sensitivity/ } \\
\mu \mathrm{A} \mu \mathbf{M}^{-1} \mathrm{~cm}^{-2}\end{array}$ & $\begin{array}{l}\text { Correlation } \\
\text { Coefficient } / \mathbf{R}^{2}\end{array}$ & $\begin{array}{l}\text { LOD } \\
* / \mu \mathrm{M}\end{array}$ & $L Q / \mu M$ & $\underset{\%}{\text { RSD }_{\%}^{* *}}$ \\
\hline \multirow{2}{*}{$\mathrm{CV}$} & \multirow{2}{*}{ CCB oxidation } & -0.40 & 0.257 & 0.971 & 0.021 & 0.038 & 0.10 \\
\hline & & 0.40 & 0.050 & 0.966 & 0.590 & 1.970 & 1.02 \\
\hline \multirow[t]{2}{*}{ DPV } & \multirow[t]{2}{*}{$\mathrm{CCB}$ reduction } & \multirow[t]{2}{*}{-1.02} & $\begin{array}{c}111.0(\mathrm{CCB} \\
\text { concentration lower } \\
\text { than } 2.5 \mu \mathrm{M})\end{array}$ & 0.990 & 0.010 & 0.250 & 2.50 \\
\hline & & & $\begin{array}{c}11.43(\mathrm{CCB} \\
\text { concentration } \\
\text { higher than } 2.5 \mu \mathrm{M})\end{array}$ & 0.960 & 0.734 & 2.446 & 2.50 \\
\hline \multirow{2}{*}{ MPA } & \multirow{2}{*}{$\begin{array}{l}\text { CCB reduction and } \\
\text { oxidation }\end{array}$} & -1.1 & 3.040 & 0.985 & 0.158 & 0.527 & 0.84 \\
\hline & & -0.4 & 0.314 & 0.989 & 0.103 & 0.343 & 0.68 \\
\hline
\end{tabular}

${ }^{*}$ The limit of detection was measured under $3 \mathrm{Sb} / \mathrm{m} .{ }^{* *}$ relative standard deviation was determined for three replicates.

Table 3. Comparison of the limit of detection for CCB electrochemical detection using a different electrode material.

\begin{tabular}{ccc}
\hline Electrode & Limit of Detection $/ \boldsymbol{\mu M}$ & Reference \\
\hline Glassy carbon & 0.113 & {$[47]$} \\
$\mathrm{ZnO} / \mathrm{MWCNT} / \mathrm{CPE}$ & 0.030 & {$[50]$} \\
$\mathrm{AuNPs} / \mathrm{SGNF} / \mathrm{GCE}$ & 0.017 & {$[52]$} \\
$\mathrm{LaFeO}_{3} / \mathrm{BDD}$ & 0.010 & This work \\
\hline
\end{tabular}

\section{Conclusions}

In the present work, $\mathrm{LaFeO}_{3}$ powders were synthesized using a new method, based on the thermal decomposition of in situ obtained $\mathrm{LaFe}\left(\mathrm{C}_{2} \mathrm{O}_{4}\right)_{3} \cdot 3 \mathrm{H}_{2} \mathrm{O}$ compound.

Single phase $\mathrm{LaFeO}_{3}$ powders with orthorombic Pbnm perovskite structure were obtained after annealing at temperatures ranging between 550 and $800{ }^{\circ} \mathrm{C}$. The crystallinity degree reflected in the values of the average crystallite size increases as the annealing temperature increased. Concurrently, a contraction of the unit cell volume is induced by the increase of the annealing temperature. Small particles, with sizes below $20 \mathrm{~nm}$ and with a high aggregation tendency, were obtained after annealing at $550{ }^{\circ} \mathrm{C}$. Even if the increase of the annealing temperature at $800^{\circ} \mathrm{C}$ induces a coarsening process, the size of the $\mathrm{LaFeO}_{3}$ particles was kept in the nanometric range $(\sim 70 \mathrm{~nm})$. However, a clear tendency to form partially-sintered blocks due to the coalescence of the small particles into larger, polyhedral grains with well-defined boundaries was noticed for the $\mathrm{LaFeO}_{3}$ sample calcined at $800{ }^{\circ} \mathrm{C}$.

The $\mathrm{LaFeO}_{3} / \mathrm{BBD}$ electrode exhibited the electrocatalytic activity toward the capecitabine (CCB) oxidation and reduction depending on the applied potential range and scanning direction that influenced the iron redox systems, considered as a basis for developing detection methods. Cyclic voltammetry $(\mathrm{CV})$ and differential-pulsed voltammetry (DPV) techniques operated under specific working conditions allowed us to develop the $\mathrm{CCB}$ voltammetric detection method. The best analytical performance was reached using DPV based on the CCB reduction mechanism. Multiple-pulsed amperometry operated under three potential levels implied CCB oxidation and a reduction mechanism, which allows CCB detection in the same time at the two potential values of $-1.1 \mathrm{~V} / \mathrm{SCE}$ and $-0.4 \mathrm{~V} / \mathrm{SCE}$ corresponding to $\mathrm{CCB}$ reduction and respective oxidation. The results of electroanalytical performance for CCB detection and its flexibility for anodic and/or cathodic detection made the $\mathrm{LaFeO}_{3} / \mathrm{BDD}$ electrode have great potential for selective or simultaneous detection of CCB in aqueous matrix.

Author Contributions: Methodology, R.D. and F.M. Investigation, S.N., C.P., B.V., and A.S.; Data curation, R.D., S.N., A.I., C.P., B.V., A.S., and F.M. Writing-original draft preparation, R.D., A.I., and F.M. Writing-review and editing, R.D. and F.M. All authors have read and agreed to the published version of the manuscript. 
Acknowledgments: This work was supported partially by research grant GNaC2018-ARUT, no. 1350/01.02.2019, financed by Politehnica University of Timisoara and partially by a grant of the Romanian Ministery of Research and Innovation, project number PN-III-P1-1.2-PCCDI-2017-0245/26 PCCDI/2018 (SUSTENVPRO), within PNCDI III.

Conflicts of Interest: The authors declare no conflict of interest.

\section{References}

1. Addabbo, T.; Bertocci, F.; Fort, A.; Gregorkiewitz, M.; Mugnaini, M.; Spinicci, R.; Vignoli, V. Gas sensing properties and modeling of $\mathrm{YCoO}_{3}$ based perovskite materials. Sens. Actuators B Chem. 2015, 221, 1137-1155. [CrossRef]

2. Natile, M.M.; Ponzoni, A.; Concina, I.; Glisenti, A. Chemical tuning versus microstructure features in solid-state gas sensors: $\mathrm{LaFe}_{1-x} \mathrm{Ga}_{x} \mathrm{O}_{3}$, a case study. Chem. Mater. 2014, 26, 1505-1513. [CrossRef]

3. Kersen, U. Microstructural and surface characterization of solid state sensor based on $\mathrm{LaFeO}_{3-\sigma}$ oxide for detection of NO. Analyst 2001, 126, 1377-1381. [CrossRef] [PubMed]

4. Phan, T.T.N.; Nikoloski, A.N.; Bahri, P.A.; Li, D. Facile fabrication of perovskite-incorporated hierarchically mesoporous/macroporous silica for efficient photoassisted-Fenton degradation of dye. Appl. Surf. Sci. 2019, 491, 488-496. [CrossRef]

5. Takalkar, G.; Bhosale, R.; AlMomani, F. Combustion synthesized $\mathrm{A}_{0.5} \mathrm{Sr}_{0.5} \mathrm{MnO}_{3-\delta}$ perovskites (where, $\mathrm{A}=\mathrm{La}$, $\mathrm{Nd}, \mathrm{Sm}, \mathrm{Gd}, \mathrm{Tb}, \mathrm{Pr}, \mathrm{Dy}$ and $\mathrm{Y}$ ) as redox materials for thermochemical splitting of $\mathrm{CO}_{2}$. Appl. Surf. Sci. 2019, 489, 80-91. [CrossRef]

6. Wang, G.; Sun, J.; Zhang, W.; Jiao, S.; Fang, B. Simultaneous determination of dopamine, uric acid and ascorbic acid with $\mathrm{LaFeO}_{3}$ nanoparticles modified electrode. Microchim. Acta 2009, 164, 357-362. [CrossRef]

7. Kumar, D.; Jayavel, R. Facile hydrothermal synthesis and characterization of $\mathrm{LaFeO}_{3}$ nanospheres for visible light photocatalytic applications. J. Mater. Sci. Mater. Electron. 2014, 25, 3953-3961. [CrossRef]

8. Bai, S.L.; Shi, B.J.; Ma, L.J.; Yang, P.C.; Liu, Z.Y.; Li, D.Q.; Chen, A.F. Synthesis of $\mathrm{LaFeO}_{3}$ catalytic materials and their sensing properties. Sci. China Ser. B Chem. 2009, 52, 2106-2113. [CrossRef]

9. Ciambelli, P.; Cimino, S.; Rossi, S.D. $\mathrm{AFeO}_{3}(\mathrm{~A}=\mathrm{La}, \mathrm{Nd}, \mathrm{Sm})$ and $\mathrm{LaFe}_{1-x} \mathrm{Mg}_{\mathrm{x}} \mathrm{O}_{3}$ perovskites as methane combustion and $\mathrm{CO}$ oxidation catalysts: Structural, redox and catalytic properties. Appl. Catal. B-Environ. 2001, 29, 239-250. [CrossRef]

10. Kuščer, D.; Hrovat, M.; Holc, J.; Bernik, S.; Kolar, D. Some characteristics of $\mathrm{Al}_{2} \mathrm{O}_{3}-$ and CaO-modified $\mathrm{LaFeO}_{3}$-based cathode materials for solid oxide fuel cells. J. Power Sources 1996, 61, 161-165. [CrossRef]

11. Grygar, $\mathrm{T}$. Electrochemical reactions of $\mathrm{La}(\mathrm{Ni}, \mathrm{Cr}) \mathrm{O}_{3}$ in acidic aqueous solutions. J. Solid State Electrochem. 1999, 3, 412-416. [CrossRef]

12. Peng, Q.; Shan, B.; Wen, Y.; Chen, R. Enhanced charge transport of $\mathrm{LaFeO}_{3}$ via transition metal (Mn, $\left.\mathrm{Co}, \mathrm{Cu}\right)$ doping for visible light photoelectrochemical water oxidation. Int. J. Hydrog. Energy 2015, 40, 15423-15431. [CrossRef]

13. Yuan, Y.; Dong, Z.; Li, Y.; Zhang, L.; Zhao, Y.; Wang, B.; Han, S. Electrochemical properties of $\mathrm{LaFeO}_{3}-\mathrm{rGO}$ composite. Proc. Nat. Sci. Mater. 2017, 27, 88-92. [CrossRef]

14. Zhang, Q.; Shan, X.; Fu, Y.; Liu, P.; Li, X.; Liu, B.; Zhang, L.; Li, D. Electrochemical determination of the anticancer drug capecitabine based on a graphene-gold nanocomposite-modified glassy carbon electrode. Int. J. Electrochem. Sci. 2017, 12, 10773-10782. [CrossRef]

15. Haron, W.; Wisitsoraatb, A.; Wongnawa, S. Nanostructured perovskite oxides- $\mathrm{LaMO}_{3}(\mathrm{M}=\mathrm{Al}, \mathrm{Co}, \mathrm{Fe})$ prepared by co-precipitation method and their ethanol-sensing characteristics. Ceram. Int. 2017, 43, 5032-5040. [CrossRef]

16. Phokha, S.; Pinitsoontorn, S.; Maensiri, S.; Rujirawat, S. Structure, optical and magnetic properties of $\mathrm{LaFeO}_{3}$ nanoparticles prepared by polymerized complex method. J. Sol-Gel Sci. Technol. 2014, 71, 333-341. [CrossRef]

17. Mitra, A.; Mahapatra, A.S.; Mallick, A.; Shaw, A.; Ghosh, M.; Chakrabarti, P.K. Simultaneous enhancement of magnetic and ferroelectric properties of $\mathrm{LaFeO}_{3}$ by co-doping with $\mathrm{Dy}^{3+}$ and $\mathrm{Ti}^{4+}$. J. Alloys Compd. 2017, 726, 1195-1204. [CrossRef]

18. Dohnalová, Ž.; Šulcová, P.; Trojan, M. Synthesis and characterization of $\mathrm{LnFeO}_{3}$ pigments. J Therm. Anal. Calorim. 2008, 91, 559-563. [CrossRef]

19. Anajafi, Z.; Naseri, M.; Neri, G. Optical, magnetic and gas sensing properties of $\mathrm{LaFeO}_{3}$ nanoparticles synthesized by different chemical methods. J. Electron. Mater. 2019, 48, 6503-6511. [CrossRef] 
20. Dai, Z.; Lee, C.S.; Kim, B.Y.; Kwak, C.H.; Yoon, J.W.; Jeong, H.M.; Lee, J.H. Honeycomb-like periodic porous $\mathrm{LaFeO}_{3}$ thin film chemiresistors with enhanced gas-sensing performances. ACS Appl. Mater. Interfaces 2014, 6, 16217-16226. [CrossRef]

21. Malik, R.; Tomer, V.K.; Mishra, Y.K.; Lin, L. Functional gas sensing nanomaterials: A panoramic view. Appl. Phys. Rev. 2020, 7, 021301. [CrossRef]

22. Kumar, Y.; Pradhan, S.; Pramanik, S.; Bandyopadhyay, R.; Das, D.K.; Pramanik, P. Efficient electrochemical detection of guanine, uric acid and their mixture by composite of nano-particles of lanthanides ortho-ferrite $\mathrm{XFeO}_{3}(\mathrm{X}=\mathrm{La}, \mathrm{Gd}, \mathrm{Pr}, \mathrm{Dy}, \mathrm{Sm}, \mathrm{Ce}$ and Tb). J. Electroanal. Chem. 2018, 830-831, 95-105. [CrossRef]

23. Bidrawn, F.; Kim, G.; Aramrueang, N.; Vohs, J.M.; Gorte, R.J. Dopants to enhance SOFC cathodes based on Sr-doped $\mathrm{LaFeO}_{3}$ and $\mathrm{LaMnO}_{3}$. J. Power Sources 2010, 195, 720-728. [CrossRef]

24. Murata, K.; Fukui, T.; Abe, H.; Naito, M.; Nogi, K. Morphology control of La(Sr)Fe(Co)O $\mathrm{O}_{3-a}$ cathodes for IT-SOFCs. J. Power Sources 2005, 145, 257-261. [CrossRef]

25. Yang, Z.; Huang, Y.; Dong, B.; Li, H.L. Controlled synthesis of highly ordered $\mathrm{LaFeO}_{3}$ nanowires using a citrate-based sol-gel route. Mater. Res. Bull. 2006, 41, 274-281. [CrossRef]

26. Lebid, M.; Omari, M. Synthesis and electrochemical properties of $\mathrm{LaFeO}_{3}$ oxides prepared via sol-gel method. Arab. J. Sci. Eng. 2014, 39, 147-152. [CrossRef]

27. Zhang, Q.; Saito, F. Effect of $\mathrm{Fe}_{2} \mathrm{O}_{3}$ crystallite size on its mechanochemical reaction with $\mathrm{La}_{2} \mathrm{O}_{3}$ to form $\mathrm{LaFeO}_{3}$. J. Mater. Sci. 2001, 36, 2287-2290. [CrossRef]

28. Kemeng, J.; Hongxing, D.; Jiguang, D.; Song, L.; Shaohua, X.; Han, W. Glucose assisted hydrothermal preparation of porous $\mathrm{LaFeO}_{3}$ for toluene combustion. J. Solid State Chem. 2013, 199, 164-170. [CrossRef]

29. Yang, J.; Li, R.; Zhou, J.; Li, X.; Zhang, Y.; Long, Y.; Li, Y. Synthesis of $\mathrm{LaMO}_{3}(\mathrm{M}=\mathrm{Fe}, \mathrm{Co}, \mathrm{Ni})$ using nitrate or nitrite molten salts. J. Alloys Compd. 2010, 508, 301-308. [CrossRef]

30. Wang, Y.; Zhu, J.; Zhang, L.; Jang, X.; Lu, L.; Wang, X. Preparation and characterization of perovskite $\mathrm{LaFeO}_{3}$ nanocrystals. Mater. Lett. 2006, 60, 1767-1770. [CrossRef]

31. Zhu, C.; Nobuta, A.; Nakatsugawa, I.; Akiyama, T. Solution combustion synthesis of $\mathrm{LaMO}_{3}(\mathrm{M}=\mathrm{Fe}, \mathrm{Co}$, $\mathrm{Mn})$ perovskite nanoparticles and the measurement of their electrocatalytic properties for air cathode. Int. J. Hydrog. Energy 2013, 38, 13238-13248. [CrossRef]

32. Prado-Gonjal, J.; Arévalo-López, Á.M.; Morán, E. Microwave-assisted synthesis: A fast and efficient route to produce $\mathrm{LaMO}_{3}(\mathrm{M}=\mathrm{Al}, \mathrm{Cr}, \mathrm{Mn}, \mathrm{Fe}, \mathrm{Co})$ perovskite materials. Mater. Res. Bull. 2011, 46, 222-230. [CrossRef]

33. Fabian, F.A.; Pedra, P.P.; Filho, J.L.S.; Duque, J.G.S.; Meneses, C.T. Synthesis and characterization of $\mathrm{La}(\mathrm{Cr}$, $\mathrm{Fe}, \mathrm{Mn}) \mathrm{O}_{3}$ nanoparticles obtained by co-precipitation method. J. Magn. Magn. Mater. 2015, 379, 80-83. [CrossRef]

34. Popa, M.; Franti, J.; Kakihama, M. Lanthanum ferrite $\mathrm{LaFeO}_{3+\mathrm{d}}$ nanopowders obtained by the polymerizable complex method. Solid State Ionics 2002, 154-155, 437-445. [CrossRef]

35. Patron, L.; Budrugeac, P.; Balu, A.; Carp, O.; Diamandescu, L.; Feder, M. Thermal analysis of some polynuclear coordination compounds. Ligand tartarate, precursors of $\mathrm{LnFeO}_{3}$ perovskites. J. Therm. Anal. Calorim 2007, 88, 273-277. [CrossRef]

36. Carp, O. Materials obtained by solid-state thermal decomposition of coordination compounds and metal-organic coordination polymers. In Reactions and Mechanisms in Thermal Analysis of Advanced Materials; Tiwari, A., Raj, B., Eds.; Scrivener Publishing LLC: Beverly, MA, USA, 2015; pp. 63-84. [CrossRef]

37. Dumitru, R.; Manea, F.; Pacurariu, C.; Lupa, L.; Pop, A.; Cioabla, A.; Surdu, A.; Ianculescu, A. Synthesis, characterization of nanosized $\mathrm{ZnCr}_{2} \mathrm{O}_{4}$ and its photocatalytic performance in the degradation of humic acid from drinking water. Catalysts 2018, 8, 210. [CrossRef]

38. Niculescu, M.; Birzescu, M.; Dumitru, R.; Sisu, E.; Budrugeac, P. Co(II)-Ni(II) heteropolynuclear coordination compound obtained through the reaction of 1,2-propanediol with metallic nitrates as precursor for mixed oxide of spinel type $\mathrm{NiCo}_{2} \mathrm{O}_{4}$. Thermochim. Acta 2009, 493, 1-5. [CrossRef]

39. Stefanescu, M.; Sasca, V.; Birzescu, M. Thermal behaviour of the homopolynuclear glyoxylate complex combinations with $\mathrm{Cu}(\mathrm{II})$ and $\mathrm{Cr}(\mathrm{III})$. J. Therm. Anal. Calorim. 2003, 72, 515-524. [CrossRef]

40. Caizer, C.; Stefanescu, M.; Muntean, C.; Hrinca, I. Studies and magnetic properties of Ni-Zn ferrite synthesized from the glyoxilates complex combination. J. Optoelectron. Adv. Mater. 2001, 3, 919-924.

41. Bîrzescu, M.; Niculescu, M.; Dumitru, R.; Budrugeac, P.; Segal, E. Copper(II) oxalate obtained through the reaction of 1,2-ethanediol with $\mathrm{Cu}\left(\mathrm{NO}_{3}\right)_{2} \cdot 3 \mathrm{H}_{2} \mathrm{O}$. J. Therm. Anal. Calorim. 2008, 94, 297-303. [CrossRef] 
42. Bîrzescu, M.; Niculescu, M.; Dumitru, R.; Carp, O.; Segal, E. Synthesis, structural characterization and thermal analysis of the cobalt(II) oxalate obtained through the reaction of 1,2-ethanediol with $\mathrm{Co}\left(\mathrm{NO}_{3}\right)_{2} \cdot 6 \mathrm{H}_{2} \mathrm{O}$. J. Therm. Anal. Calorim. 2009, 96, 979-986. [CrossRef]

43. Dumitru, R.; Manea, F.; Lupa, L.; Păcurariu, C.; Ianculescu, A.; Baciu, A.; Negrea, S. Synthesis, characterization of nanosized $\mathrm{CoAl}_{2} \mathrm{O}_{4}$ and its electrocatalytic activity for enhanced sensing application. J. Therm. Anal. Calorim. 2017, 128, 1305-1312. [CrossRef]

44. Dumitru, R.; Ianculescu, A.; Păcurariu, C.; Lupa, L.; Pop, A.; Vasile, B.; Surdu, A.; Manea, F. BiFeO 3 -synthesis, characterization and its photocatalytic activity towards doxorubicin degradation from water. Ceram. Int. 2019, 45, 2789-2802. [CrossRef]

45. Dumitru, R.; Papa, F.; Balint, I.; Culita, D.; Munteanu, C.; Stanica, N.; Ianculescu, A.; Diamandescu, L.; Carp, O. Mesoporous cobalt ferrite: A rival of platinum catalyst in methane combustion reaction. Appl. Catal. A Gen. 2013, 467, 178-186. [CrossRef]

46. Patrinoiu, G.; Dumitru, R.; Culita, D.C.; Munteanu, C.; Birjega, R.; Calderon-Moreno, J.M.; Cucos, A.; Pelinescu, D.; Chifiriuc, M.C.; Bleotu, C.; et al. Self-assembled zinc oxide hierarchical structures with enhanced antibacterial properties from stacked chain-like zinc oxalate compounds. J. Colloid Interface Sci. 2019, 552, 258-270. [CrossRef]

47. Kalanur, S.S.; Seetharamappa, J.; Mamatha, G.P.; Hadagali, M.D.; Kandagal, P.B. Electrochemical behavior of an anti-cancer drug at glassy carbon electrode and its determination in pharmaceutical formulations. Int. J. Electrochem. Sci. 2008, 3, 756-767.

48. Bariş̧̧i, S.; Turkay, O.; Ulusoy, E.; Şeker, M.G.; Yüksel, E. Electro-oxidation of cytostatic drugs: Experimental and theoretical identification of by-products and evaluation of ecotoxicological effects. Chem. Eng. J. 2018, 334, 1820-1827. [CrossRef]

49. Xie, H. Occurrence, ecotoxicology, and treatment of anticancer agents as water contaminants, environmental\&analytical toxicology. J. Environ. Anal. Toxicol. 2012, S2, 002. [CrossRef]

50. Madrakian, T.; Ghasemi, H.; Haghshenas, E.; Afkhami, A. Preparation of a ZnO nanoparticles/multiwalled carbon nantubes/carbon paste electrode a sensitive tool for capecitabine determination in real samples. RSC Adv. 2016, 6, 33851-33856. [CrossRef]

51. Deng, P.; Ji, C.; Dai, X.; Zhong, D.; Ding, L.; Chen, X. Simultaneous determination of capecitabine and its three nucleoside metabolites in human plasma by high performance liquid chromatography-tandem mass spectrometry. J. Chromatogr. 2015, 989, 71-79. [CrossRef]

52. Zhang, G.H.; Chen, Q.; Deng, X.Y.; Jiao, H.Y.; Wang, P.Y.; Gengzang, D.J. Synthesis and characterization of In-doped $\mathrm{LaFeO}_{3}$ hollow nanofibers with enhanced formaldehyde sensing properties. Mater. Lett. 2017, 236, 229-232. [CrossRef]

53. Teixeira, P.R.S.; Teixeira, A.S.D.M.; Farias, E.A.D.; Filho, E.C.S.; Cunha, H.N.; Santos Junior, J.R.; Nunes, L.C.C.; Lima, H.R.S.; Eiras, C. Development of a low-cost electrochemical sensor based on babassu mesocarp (Orbignya phalerata) immobilized on a flexible gold electrode for applications in sensors for 5-fluorouracil chemotherapeutics. Anal. Bioanal. Chem. 2019, 411, 659-667. [CrossRef] [PubMed]

54. Fujita, J.; Nakamoto, K.; Kobayshi, M. Infrared spectra of metallic complexes. II. The absorption bands of coördinated water in aquo complexes. J. Am. Chem. Soc. 1956, 78, 3963-3965. [CrossRef]

55. Nakamoto, K. Infrared and Raman Spectra of Inorganic and Coordination Compounds; Wiley: New York, NY, USA, 1986.

56. Bellakki, M.B.; Manivannan, V.; McCurdy, P.; Kohli, S. Synthesis, and measurement of structural and magnetic properties, of $\mathrm{La}_{1-x} \mathrm{Na}_{x} \mathrm{FeO}_{3}(0.0 \leq x \leq 0.3)$ perovskite oxides. J. Rare Earth 2009, 27, 691-697. [CrossRef]

57. Dai, X.; Yu, C.; Li, R.; Wu, Q.; Shi, K.; Hao, Z. Effect of calcination temperature and reaction conditions on methane partial oxidation using lanthanum-based perovskite as oxygen donor. J. Rare Earths 2008, 26, 341-345. [CrossRef] 
58. Shivakumara, C. Low temperature synthesis and characterization of rare earth orthoferrites $\mathrm{LnFeO}_{3}\left(\mathrm{Ln}=\mathrm{La}_{\text {, }}\right.$ Pr and Nd) from molten NaOH flux. Solid State Commun. 2006, 139, 165-169. [CrossRef]

59. Ljoncheva, M.; Kosjek, T.; Isidori, M.; Heath, E. 5-Fluorouracil and its prodrug capecitabine: Occurrence, fate and effect in environment. In Fate and Effect of Anticancer Drugs in the Environment; Isidori, M., Kosjek, T., Filipic, M., Eds.; Springer: Cham, Switzerland, 2020; pp. 331-375. [CrossRef] 